\title{
Reversal of Haemostatic Changes in Letrozole-Induced PCOS Rat Model with Vitamin D Supplementation
}

\author{
SUZAN M.M. MOURSI, M.D.*; EMAN EL-BAHAIE, Ph.D.** and SHEREIN F. EL-SAYED, M.D.* \\ The Departments of Physiology, Faculty of Medicine* and Zoology, Faculty of Science**, Zagazig University
}

\begin{abstract}
Background: Polycystic ovary syndrome (PCOS) is a heterogeneous endocrine condition that appears to be associated with a prothrombotic tendency. Hypovitaminosis D is very common in PCOS patients and may exacerbate the metabolic abnormalities. Vitamin D supplementation might produce beneficial effects in these associated metabolic and haemostatic abnormalities.
\end{abstract}

Aim of Study : The present study was designed to examine the effects of vitamin D supplementation on some metabolic, oxidative stress, inflammatory and haemostatic parameters in letrozole-induced PCOS rat models.

Material and Methods: This study was conducted on 3 groups of adult female albino rats: Group-1: (Control) in which $1 \mathrm{ml}$ water was given orally by gavage daily for 21 days, and, group-II: (PCOS induced) in which letrozole was given orally by gavage at a dose of $1 \mathrm{mg} / \mathrm{kg}$ dissolved in water daily for 21 days, and group-III: (PCOS induced treated with vitamin D) in which letrozole was given orally by gavage with cholecalciferol (200 IU/day) for 21 days. In all groups, serum levels of $25(\mathrm{OH})$ vitamin D, glucose, insulin, HOMAIR, lipid profile parameters, Luteinizing hormone (LH), Follicle-stimulating hormone (FSH), testosterone, estradiol, progesterone, interleukin-6 (IL-6), tumor necrosis factoralpha (TNF- $\alpha$ ), plasma fibrinogen, factor VIII (FVIII), Von Willebrand factor (vWF), tissue plasminogen activator (tPA), plasminogen activator inhibitor 1 (PAI-1) activity and Ddimers levels were measured. Bleeding time (BT), whole blood clotting time (WBCT), prothrombin time (PT), activated partial thromboplastin time (aPTT) were also evaluated and ovaries were dissected and used for histopathological examination and evaluating malondialdehyde (MDA), superoxide dismutase (SOD) and glutathione peroxidase (GPx) levels.

Results: The present study showed that letrozole-induced PCOS rat group (II) showed a statistically significant increase in the serum levels of insulin, glucose and calculated HOMAIR, Cholesterol, Triglyceride, LDL-c, VLDL-c, testosterone, FSH, LH, TNF-a, IL-6, ovarian MDA, plasma FVIII, Vwf, D-dimers, PAI-1 activity and fibrinogen levels (with statistically significant negative correlations with serum vitamin D level) while there were a statistically significant decrease in

Correspondence to: Dr. : Eman El-Bahaie,

E-Mail: e.elbahaie@yahoo.com the serum levels of $25(\mathrm{OH})$ vitamin D and HDL-c, estradiol, progesterone, ovarian SOD and GPx, bleeding and clotting times, PT and aPTT when compared to controls (with statistically significant positive correlations with serum vitamin D level). Interestingly, all of the above measures were improved with vitamin D3 supplementation in the treated group (III). Also, vitamin D3 supplementation reduced the size and number of the cystically dilated ovarian follicles observed in the histopathological examination of letrozole-induced PCOS group.

Conclusion: PCOS are associated with hypovitaminosis $\mathrm{D}$ and characterized by metabolic disturbances and a prothrombotic state that can be explained by increased both insulin resistance and inflammatory mediators together with the development of oxidative stress. These changes were improved by vitamin D supplementation.

Key Words: PCOS - Haemostasis - Vitamin D.

\section{Introduction}

POLYCYSTIC ovary syndrome (PCOS), the most common endocrine abnormality in premenopausal women, is characterized by hyperandrogenism, ovulatory dysfunction, and PCO morphology [1]

Several studies pointed to a prothrombotic state in PCOS including hypofibrinolysis, hypercoagulability, and endothelial \& platelet dysfunction $[2,3]$. Others point in the opposite direction or suggest an unaffected fibrinolysis/coagulation status $[4,5]$.

The mechanisms of potential disturbances of the hemostatic system in women with PCOS are unknown. There is evidence that plasma levels of several hemostatic factors are modulated by hyperglycemia, insulin resistance with compensatory hyperinsulinemia, proinflammatory agents, and dyslipidemia, all of which are typical in PCOS [6]

On another note, Vitamin D is a fat-soluble vitamin that belongs to the family of steroid hormones. Its biological actions are exerted through 
the vitamin D receptor (VDR), a transcription factor located in the nuclei of target cells that mediates the genomic action of the active form of vitamin $\mathrm{D}$. The presence of VDR in female reproductive tissue suggests that vitamin $\mathrm{D}$ is involved in female reproduction [7]. VD deficiency (VDD) is also common in women with polycystic ovary syndrome (PCOS), with the $67-85 \%$ of women with PCOS having serum concentrations of 25hydroxy Vitamin D (25OHD) <20ng/ml [8] .

Data regarding the association between VDD and PCOS are apparently conflicting; some authors showed association of low 25 hydroxy vitamins (25OHD) with metabolic derangements of PCOS $[9,10]$ suggesting that VDD might be a causal factor in the pathogenesis of PCOS while others demonstrated no such association [11,12].

There has been a growing interest in recent years regarding non-classical effects of vitamin $\mathrm{D}$, and current evidence suggests that there is increased risk of disorders like type 2 diabetes mellitus, cardiovascular disease, hypertension, IR, dyslipidaemia and obesity with VDD [13,14]. Moreover, Patients with low vitamin D levels are more prone to thrombosis but there was limited data concerning the pro-fibrinolytic, antitrombotic effect of vitamin D [15]

On the other hand, several studies had shown that the vitamin D supplementation might improve IR and reduce serum androgens in PCOS [16] Seyyed Abootorabia et al., [17] also showed improved fasting plasma glucose, HOMA-B, adiponectin, and serum vitamin $\mathrm{D}$ level by Vitamin $\mathrm{D}$ supplementation in vitamin $\mathrm{D}$ deficient women with PCOS. However, another study failed to observe a positive influence of vitamin D3 supplementation on insulin-sensitivity [12]

Therefore, the aim of this study was to examine the relationship between serum level of vitamin $D$ and PCOS metabolic and haemostatic parameters and to evaluate the effect of vitamin D3 oral supplementation on these parameters in letrozoleinduced PCOS rat models.

\section{Material and Methods}

This study was conducted in Faculty of Medicine, Zagazig University in the period from June 2018 to February 2019 and involved thirty healthy adult female albino rats of local strain weighing $190-217 \mathrm{~g}$ obtained from faculty of veterinary medicine animal house. Rats were kept under hygienic conditions in steel wire cages (5/cage) at room temperature, maintained on a natural light/dark cycle with free access to water and adapted to the new environment for one week before the experiment going on. All experimental procedures were approved by the Institutional Research Board and Ethics Committee of Faculty of Medicine, Zagazig University.

Rats were randomly assigned to three equal groups: Group (I): (Control) in which $1 \mathrm{ml}$ water was given orally by gavage daily for 21 days, group (II): (PCOS induced) in which letrozole (ACDIMA international) was given orally by gavage at a dose of $1 \mathrm{mg} / \mathrm{kg}$ dissolved in water daily for 21 days. This dose was chosen according to the previous study in which the cystic follicle formation was induced [18], and group (III): (Vitamin D3 treated PCOS induced) in which letrozole was given orally by gavage at a dose of $1 \mathrm{mg} / \mathrm{kg}$ dissolved in water with cholecalciferol (200IU/day) [19] daily for 21 days (Vidrop oral drops $2800 \mathrm{IU} / \mathrm{ml}$ (each drop contains 1001 U of vitamin D).

\section{Determination of sexual cycle:}

Vaginal smears were prepared daily by vaginal washing with saline then the fresh unstained samples were examined microscopically during the period of treatment, and cycles with duration of 4-5 days were considered regular [20]. Determination of estrus phases were done according to Goldman et al., [21].

Sample collection: Retro-orbital venous plexus blood samples $(6 \mathrm{ml})$ were collected and divided into three vials. The first one $(2 \mathrm{ml})$ was containing $3.2 \%$ sodium citrate in the ratio 1:9 with the blood and centrifuged at 2000rpm for $15 \mathrm{~min}$ (sampling of controls were taken in the estrus phase). Plasma obtained was used for estimation of prothrombin time (PT), activated partial thromboplastin time (aPTT), plasma FVIII, vWF, (tPA), PAI-1 activity, D-dimers and fibrinogen levels. The second vial $(2 \mathrm{ml})$ was used to separate serum. It was obtained by allowing the blood samples to clot then centrifugation at $3000 \mathrm{rpm}$ for 20 minutes and kept at $\left(-20^{\circ} \mathrm{C}\right)$ and used to measure levels of, glucose, in- sulin, total cholesterol (TC), triglycerides (TG), high density lipoproteins cholesterol (HDL-c), very low density lipoproteins cholesterol (VLDL-c), low density lipoproteins cholesterol (LDL-c), tumor necrosis factor-alpha (TNF- (x), interleukin-6 (IL6), LH, FSH, testosterone, estradiol and progesterone. The third vial was filled with fresh blood (2ml) for measuring the whole blood clotting time (WBCT). The ovaries were dissected and right ovaries were frozen immediately at $-70^{\circ} \mathrm{C}$ until used for determination of oxidative stress markers 
whereas, left ovaries were used for histopathological examination.

\section{- Biochemical analysis:}

Measurement of serum vitamin D: Serum vitamin D was estimated as described by Holick [22] using 25(OH) vitamin D ELISA kit (Sigma-Aldrich Co, Egypt).

\section{Measurement of serum glucose and insulin:}

Serum glucose was estimated as described by Tietz [23] using specific glucose kit (Bioscience, Egypt) and analyzed by spectrophotometer device (URIT-810, China) at 546nm wave length.

Insulin was measured as described by Temple et al., [24] using specific insulin kit (BioSource Belgium) and analyzed by spectrophotometer device at $450 \mathrm{~nm}$ wave length.

Calculation of Homeostasis model assessment of insulin resistance (HOMA-IR): Was calculated according to the following formula:

[HOMA-IR=Insulin $(\mathrm{U} / \mathbf{m L}) \times$ glucose $(\mathrm{mg} /$ dl)/405] [25]

\section{Measurement of serum lipids profile:}

TC and TG were measured by enzymatic colorimetric method described by Tietz [23] using specific cholesterol and triglycerides kits (Spinreact Spain) and analyzed by spectrophotometer device at 500 $\mathrm{nm}$ wave length. HDL-c was measured by precipitating reagent method described by Tietz et al., [23] using HDL-c precipitating reagent kit (Spinreact, Spain) and analyzed by spectrophotometers device at $600 \mathrm{~nm}$ wave length. LDL-c and VLDLc were measured by using Friedewald et al., [26] formula.

$$
\text { LDLc }=\text { TC-HDLc }-\left(\frac{\mathrm{TG}}{5}\right) \mathrm{VLDc}=\frac{\mathrm{TG}}{5 .}
$$

\section{Measurement of serum sex hormones:}

Serum FSH level was measured according to Rebar et al., [27] using Follicle-Stimulating Hormone (FSH) enzyme immunoassay test kit (Catalog Number: BC-1029, BioCheck, Inc 323 Vintage Park Dr. Foster City, CA 94404), measured by using spectrophotometer (spectronic 3000 Array, Germany) at $450 \mathrm{~nm}$.

Serum LH level was measured according to Tietz [23] using Luteinizing hormone (LH) enzyme immunoassay test kit (Catalog Number: BC- 1031, BioCheck, Inc 323 Vintage Park Dr. Foster City, CA 94404), was measured by using spectrophotometer (spectronic 3000 Array, Germany) at $450 \mathrm{~nm}$. Serum testosterone level was measured according to Tietz [23] using testosterone enzyme immunoassay test kit (Catalog Number: BC-1115, BioCheck, Inc 323 Vintage Park Dr. Foster City, CA 94404), was measured by using spectrophotometer (spectronic 3000 Array, Germany) at 450 $\mathrm{nm}$. Serum estradiol Level: was measured according to the method described by Tietz [23] using rat estradiol (E2) enzyme-linked immunosorbent assay kit: (Catalog Number: 2011-11-0175, shanghai sunred biological technology, china) at $280 \mathrm{~nm}$. Serum progesterone Level was measured according to the method described by Tietz [23] using rat progesterone enzyme-linked immunosorbent assay Kit: (Catalog Number: Catalog Number: 2011-110742, shanghai sunred biological technology, china) at $254 \mathrm{~nm}$.

Measurement of serum TNF- a level: Serum TNF-a level was measured as described by Fernando et al., [28], using commercial ELISA kit, (Catalog Number RAB0480, provided by SigmaAldrich Co).

Measurement of serum IL-6 level: Serum IL6 level was measured as described by Engvall and Perlmann [29], using IL-6 ELISA Kit (Catalog Number RAB0306 provided by Sigma-Aldrich Co).

Measurement of Ovarian malondialdehyde (MDA), superoxide dismutase (SOD) and glutathione peroxidase (GPx): These markers of oxidative stress were measured in ovarian tissue as described by Ohkawa et al., [30], Kakkar et al., [31] and Reddy et al., [32] respectively.

\section{- Haemostatic parameters:}

Bleeding time: It was measured according to the method described by Martin [33].

Whole blood clotting time: It was measured according to the method described by Quick, [34]

Prothrombin time: It was measured according to the method described by Arkin [35] using coagulometer (bmc coagulation analyzer 600).

Activated partial thromboplastin time: It was measured according to method of Ansell [36] using coagulometer.

Plasma fibrinogen levels: It was measured according to the method described by Cooper and Douglas [37] using coagulometer.

Plasma D-dimer level: It was measured using ELIZA kit, (GenWay Biotech, Inc, ca 40-88234402, USA) according to the method described by Declerck et al., [38] 
Plasma von willebrand factor antigen ( $v W F$ ) activity: It was measured using ELIZA kit, according to the method described by Declerck et al., [38].

Plasma plasminogen activator inhibitor 1 (PAI1) level: It was measured using ELIZA kit, according to the method described by Declerck et al., [38].

Plasma coagulation factor FVIII: It was measured using ELIZA kit that was obtained from American diagnostic according to the method described by Mannucci et al., [39].

Plasma tissue-type plasminogen activator ( $t$ $P A)$ : It was measured using t-PA ELIZA kit (catalog No: MBS2507499, provided by myobiosource) according to the method described by Ito et al., [40].

\section{Histopathological examination:}

The ovaries were dissected, fixed in $10 \%$ buffered formalin for 6 hours at room temperature and washed in a phosphate buffer saline solution. The fixed tissues were dehydrated in an ascending series of ethanol, cleared in xylene then embedded in paraffin. 5 ick sections were mounted in slides previously treated with 3-aminopyropyl triethoxysilane and stained with hematoxylin and eosin for light microscopy [41].

\section{Statistical analysis:}

Data were presented as mean \pm SD. The Statistical Package for the Social Sciences (SPSS), version 19.0 (SPSS Inc., Chicago, IL, United States) was used for performing the statistical analysis. Analysis of variance (ANOVA) followed by LSD post hoc test was performed to compare means of the different groups. Pearson's correlation analysis was performed to display possible relationships between serum vitamin $d$ and the measured parameters. $p$-value $<0.05$ was considered to be statistically significant for all statistical tests done.

\section{Results}

The present study showed that while regular sexual cycles were observed in all rats at the beginning of the experiments and in control rats, letrozole-treated rats (rats with PCOS) were acyclic and showed persistent estrus.

The present study also showed that letrozoletreated rats (group II) showed a statistically significant increase in the levels of serum insulin, glucose and calculated HOMA-IR, Cholesterol, Triglyceride, LDL-c, VLDL-c, testosterone $(p<0.001)$, FSH $(p<0.01), \mathrm{LH}, \mathrm{TNF}-\alpha, \mathrm{IL}-6$ and ovarian MDA $(p<0.001)$ in comparison to those of control group (I), while there was a statistically significant decrease in the levels of $25(\mathrm{OH})$ vitamin D, HDL-c, estradiol, progesterone, ovarian SOD and GPx $(p<0.001)$ when compared to controls.

However, PCOS rats treated with vitamin D (group III) showed a statistically significant decrease in the levels of serum insulin $(p<0.01)$, glucose and calculated HOMA-IR, Cholesterol, Triglyceride, LDL-c, VLDL-c, testosterone ( $p<$ $0.001)$, FSH, LH $(p<0.05)$ TNF- $\alpha$, IL-6 and ovarian MDA $(p<0.001)$ when compared to those of untreated letrozole-induced PCOS rats, but it showed statistically significant increases in the levels of serum $25(\mathrm{OH})$ vitamin $\mathrm{D}$, HDL-c, estradiol, progesterone, ovarian SOD and GPx $(p<0.001)$.

In addition, serum $25(\mathrm{OH})$ vitamin $\mathrm{D}$ showed statistically significant negative correlations with serum insulin, glucose, calculated HOMA-IR, Cholesterol, Triglyceride, LDL-c, VLDL-c, TNF$\alpha$, IL-6, LH, FSH, testosterone and ovarian MDA in letrozole-induced PCOS studied group. However, statistically positive correlations were found between 25(OH) vitamin D serum level and HDL-c, estradiol, progesterone and ovarian SOD, GPX levels in that group.

Moreover, statistically significant decreases in bleeding and clotting times, PT and aPTT $(p<0.001)$ with statistically significant positive correlations with serum $25(\mathrm{OH})$ vitamin $\mathrm{D}$ together with statistically significant increases in plasma FVIII, Vwf, D-dimers, PAI-1 activity and fibrinogen levels $(p<0.001)$ (with statistically significant negative correlations with serum $25(\mathrm{OH})$ vitamin $\mathrm{D})$ were observed in letrozole-induced PCOS rats that were improved with vitamin D supplementation in the treated group.

Additionally, histopathological examination of ovaries from the control group revealed numerous ovarian follicles at various grades of maturation surrounded by dense ovarian stroma (Photo 1 ). However, follicular cysts were observable on the surface of ovaries from PCOS group (II) in the form of fluid-filled sacs and histological examination revealed large cystic follicles filled by granulosa cells and surrounded by dense stroma (Photo $2)$. However, the number of cystic follicles was significantly decreased by vitamin $\mathrm{D}$ adminstration in vitamin D 3 treated PCOS group (letrozole + Vit. $D_{3}$ ) (Photo 3), but were still higher than control group. 


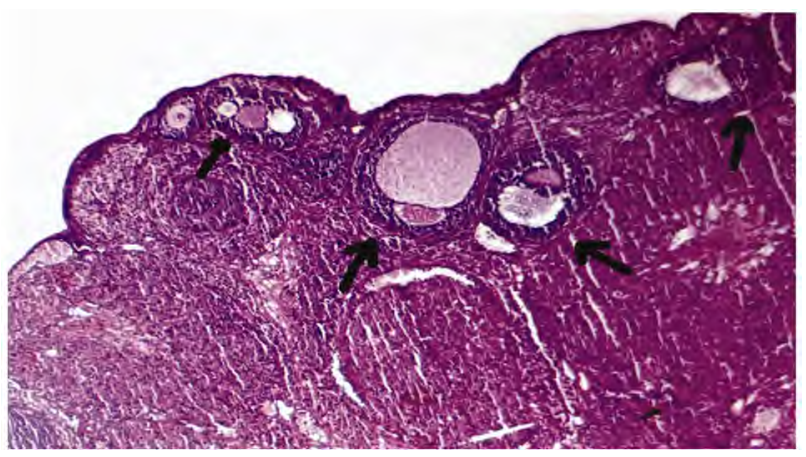

Photo (1): Photomicrograph of ovarian tissue of control group showing numerous variable sized graffian follicles (black arrows) at different stages of maturation surrounded by dense spindle shaped ovarian stroma (H\&E X200).

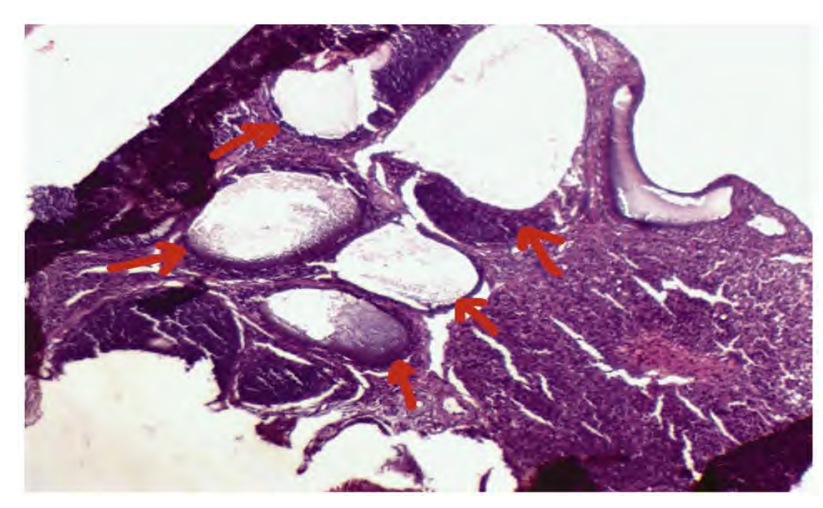

Photo (2): Photomicrograph of ovarian tissue of letrozoleinduced PCOS group showing increased cystically dilated graffian follicles (red arrows) surrounded by dense ovarian stroma (H\&E X200).

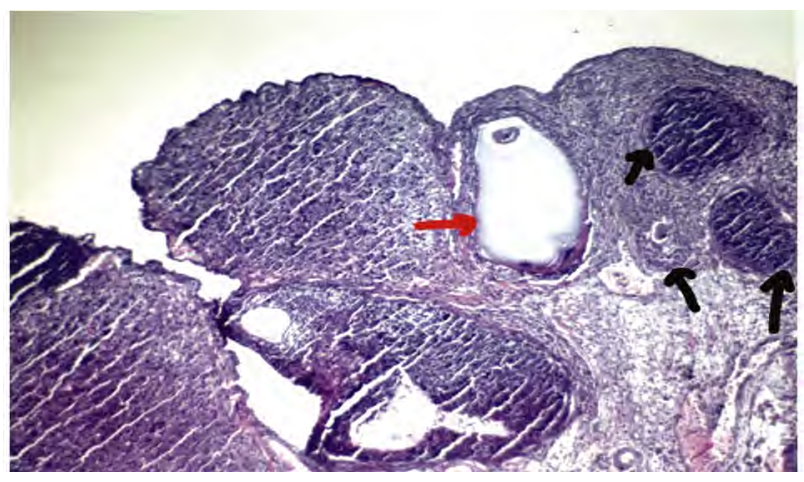

Photo (3): Photomicrograph of ovarian tissue of vitamin D 3 treated PCOS group showing reduction in the size and number of the previously cystically dilated graffian follicles (red arrows) with normal graffian follicles (black arrows) (H\&E X200).
Table (1): Biochemical Parameters of all studied groups.

\begin{tabular}{|c|c|c|c|}
\hline Parameter & Group I & Group II & Group III \\
\hline $\begin{array}{l}25(\mathrm{OH}) \text { vitamin } \mathrm{D} \\
(\mathrm{ng} / \mathrm{ml})\end{array}$ & $34.65 \pm 2.36$ & $\begin{array}{l}19.6 \pm 3.16 \\
p<0.001 \text { a }\end{array}$ & $\begin{array}{l}32.4 \pm 2.17 .4 \\
\mathrm{NSa}, p<0.001 \text { b }\end{array}$ \\
\hline Glucose (mg/dl) & $81.25 \pm 6.4$ & $\begin{array}{l}153.6 \pm 6.4 \\
p<0.001^{\mathrm{a}}\end{array}$ & $\begin{array}{r}126.65 \pm 7.3 \\
p<0.001 \mathbf{a , b}\end{array}$ \\
\hline Insulin $(\mu \mathrm{IU} / \mathrm{ml})$ & $20.58 \pm 2.1$ & $\begin{array}{l}29.5 \pm 2.1 \\
p<0.001 \mathrm{a}\end{array}$ & $\begin{array}{l}25.25 \pm 2.8 \\
p<0.001^{\mathbf{a}}, p<0.01^{\mathbf{b}}\end{array}$ \\
\hline HOMA-IR & $4.14 \pm 0.6$ & $\begin{array}{c}11.2 \pm 1.6 \\
p<0.001^{\mathbf{a}}\end{array}$ & $\begin{array}{l}7.9 \pm 1.1 \\
p<0.001 \mathbf{a , b}\end{array}$ \\
\hline $\begin{array}{l}\text { Cholesterol } \\
(\mathrm{mg} / \mathrm{dl})\end{array}$ & $73.42 \pm 5.7$ & $\begin{array}{l}126.2 \pm 9.2 \\
p<0.001 \mathrm{a}\end{array}$ & $\begin{array}{l}97.89 \pm 6.4 \\
p<0.001 \mathbf{a , b}\end{array}$ \\
\hline $\begin{array}{l}\text { Triglyceride } \\
(\mathrm{mg} / \mathrm{dl})\end{array}$ & $69.2 \pm 3.1$ & $\begin{array}{l}132.2 \pm 9 \\
p<0.001 \mathbf{a}\end{array}$ & $\begin{array}{l}80.9 \pm 6.4 \\
p<0.011^{\mathbf{a}}, p<0.001 \mathbf{b}\end{array}$ \\
\hline HDL-c (mg/dl) & $40.47 \pm 2.5$ & $\begin{array}{l}27.61 \pm 3.2 \\
p<0.001 \mathrm{a}\end{array}$ & $\begin{array}{l}34.18 \pm 2.9 \\
p<0.001 \mathbf{a , b}\end{array}$ \\
\hline LDL-c (mg/dl) & $19.11 \pm 6.4$ & $\begin{array}{l}72.14 \pm 10.1 \\
p<0.001 \text { a }\end{array}$ & $\begin{array}{l}47.53 \pm 7.3 \\
p<0.001 \mathbf{a , b}\end{array}$ \\
\hline VLDL-c (mg/dl) & $13.84 \pm 0.6$ & $\begin{array}{l}26.44 \pm 1.8 \\
p<0.001 \text { a }\end{array}$ & $\begin{array}{l}16.18 \pm 1.2 \\
p<0.01^{\mathbf{a}}, p<0.001^{\mathbf{b}}\end{array}$ \\
\hline $\begin{array}{l}\text { Testosterone } \\
(\mathrm{pg} / \mathrm{ml})\end{array}$ & $1.33 \pm 0.37$ & $\begin{array}{l}2.38 \pm 0.2 \\
p<0.001 \mathbf{a}\end{array}$ & $\begin{array}{l}1.72 \pm 0.2 \\
p<0.01^{\mathbf{a}}, p<0.001 \mathbf{b}\end{array}$ \\
\hline Estradiol (pg/ml) & $34.62 \pm 2.6$ & $\begin{array}{l}21.7 \pm 3.4 \\
p<0.001^{\mathbf{a}}\end{array}$ & $\begin{array}{l}27.37 \pm 2.7 \\
p<0.001 \mathbf{a , b}\end{array}$ \\
\hline $\begin{array}{l}\text { Progesterone } \\
(\mathrm{ng} / \mathrm{ml})\end{array}$ & $27.82 \pm 2.6$ & $\begin{array}{l}15.78 \pm 2.3 \\
p<0.001^{\mathrm{a}}\end{array}$ & $\begin{array}{l}21.69 \pm 2 \\
p<0.001 \mathbf{a , b}\end{array}$ \\
\hline LH (IU/ml) & $0.86 \pm 0.03$ & $\begin{array}{l}0.95 \pm 0.05 \\
p<0.001 \mathrm{a}\end{array}$ & $\begin{array}{l}0.90 \pm 0.02 \\
p^{<0.05} \mathbf{a}^{\prime} \mathbf{b}\end{array}$ \\
\hline FSH (IU/ml) & $4.39 \pm 0.48$ & $\begin{array}{l}4.95 \pm 0.28 \\
p<0.01^{\mathrm{a}}\end{array}$ & $\begin{array}{l}4.56 \pm 0.39 \\
\mathrm{NSa}, p^{<0.05 \mathbf{b}}\end{array}$ \\
\hline TNF- $\alpha(\mathrm{pg} / \mathrm{ml})$ & $24.75 \pm 4.2$ & $\begin{array}{l}47.07 \pm 4.5 \\
p<0.001 \mathbf{a}\end{array}$ & $\begin{array}{l}36.63 \pm 2.9 \\
p<0.001 \mathbf{a , b}\end{array}$ \\
\hline Il-6 & $8.17 \pm 0.95$ & $\begin{array}{l}21.71 \pm 3.15 \\
p<0.001^{\mathbf{a}}\end{array}$ & $\begin{array}{l}14.23 \pm 1.73 \\
p<0.001 \mathbf{a , b}\end{array}$ \\
\hline MDA (mmol/gm) & $81.3 \pm 6.3$ & $\begin{array}{l}144.79 \pm 11.45 \\
p<0.001^{\mathrm{a}}\end{array}$ & $\begin{array}{l}103.95 \pm 8.89 \\
p<0.001 \mathbf{a , b}\end{array}$ \\
\hline SOD (U/gm) & $7.51 \pm 0.5$ & $\begin{array}{l}4.37 \pm 0.76 \\
p<0.001 \text { a }\end{array}$ & $\begin{array}{l}6.07 \pm 0.68 \\
p<0.001 \mathbf{a , b}\end{array}$ \\
\hline GPx (U/gm) & $23.3 \pm 2.5$ & $\begin{array}{l}12.13 \pm 2.05 \\
p<0.001 \text { a }\end{array}$ & $\begin{array}{l}19.27 \pm 2.12 \\
p<0.001 \mathbf{a , b}\end{array}$ \\
\hline
\end{tabular}


Table (2): Haemostatic parameters of all the studied groups.

\begin{tabular}{lccc}
\hline Parameter & Group I & Group II & Group III \\
\hline BT (sec) & $93.6 \pm 3.2$ & $74.6 \pm 3.02$ & $87.2 \pm 3.25$ \\
& & $p<0.001^{\mathbf{a}}$ & $p<0.001 \mathbf{a}, \mathbf{b}$ \\
WBCT (sec) & $119.8 \pm 14.39$ & $76.6 \pm 9.33$ & $98 \pm 8.01$ \\
& & $p<0.001^{\mathbf{a}}$ & $p<0.001 \mathbf{a}, \mathbf{b}$ \\
PT (sec) & $16.4 \pm 2.01$ & $9.5 \pm 1.9$ & $12.8 \pm 1.54$ \\
& & $p<0.001 \mathbf{a}$ & $p<0.001 \mathbf{a}, \mathbf{b}$ \\
aPTT (sec) & $24.09 \pm 3.07$ & $15.9 \pm 2.51$ & $19.7 \pm 2.40$ \\
& & $p<0.001 \mathbf{a}$ & $p<0.01 \mathbf{a} \mathbf{a}$ \\
Plasma Fibrinogen (mg/dl) & $221.1 \pm 12.55$ & $323 \pm 27.1$ & $268.7 \pm 17.35$ \\
& & $p<0.001 \mathbf{a}$ & $p<0.001 \mathbf{a}, \mathbf{b}$ \\
Plasma D-dimer (mg/dl) & $63.69 \pm 3.59$ & $112.1 \pm 10.95$ & $80 \pm 9.53$ \\
& & $p<0.001 \mathbf{a}$ & $p<0.001 \mathbf{a}, \mathbf{b}$ \\
Plasma factor VIII (U/L) & $263.09 \pm 9.56$ & $310.3 \pm 14.75$ & $285.4 \pm 11.64$ \\
& & $p<0.001 \mathbf{a}$ & $p<0.001 \mathbf{a}, \mathbf{b}$ \\
Plasma Von Willebrand factor (vWF ) (ng/ml) & $92.08 \pm 3.69$ & $131.38 \pm 7.69$ & $103.37 \pm 6.27$ \\
& & $p<0.001 \mathbf{a}$ & $p<0.001 \mathbf{a}, \mathbf{b}$
\end{tabular}

$a=$ Versus group I. $\quad$ b=Versus group II. $\quad$ NS=Non-significant $(p>0.05)$.
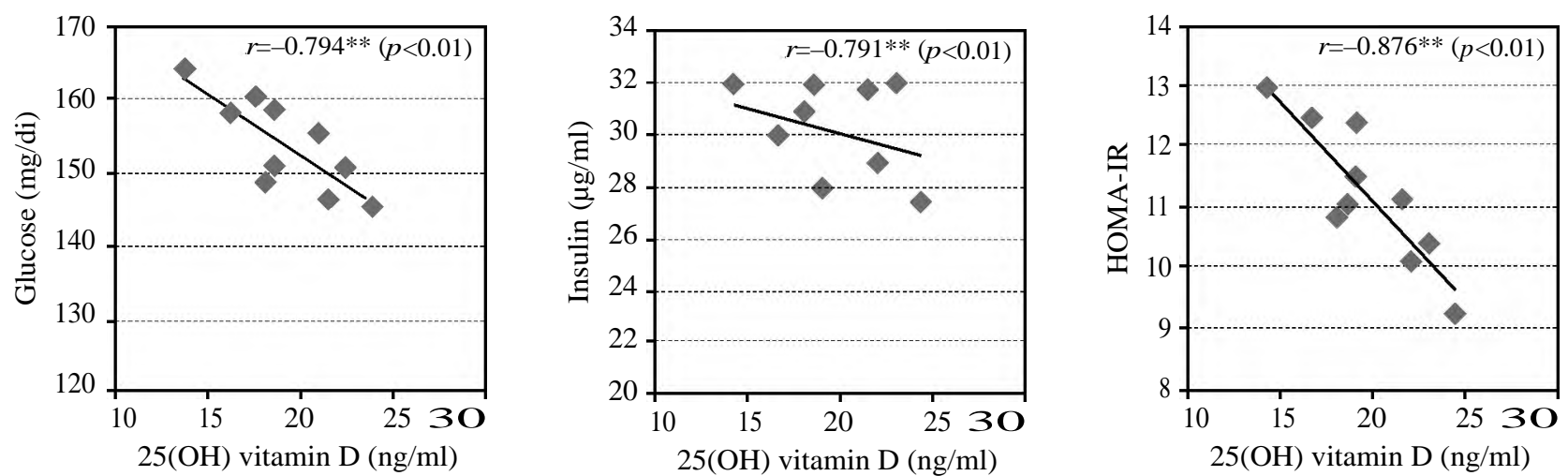

Figs. (1-3): Correlation between serum vitamin D and serum glucose, insulin and HOMA-IR respectively in group II.
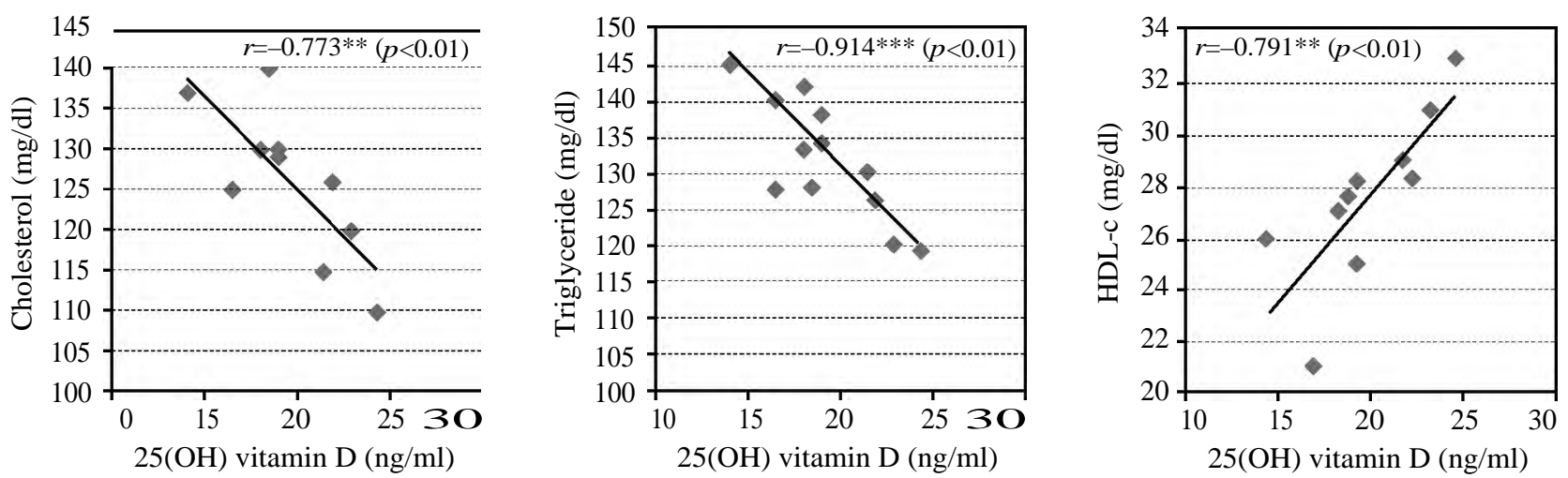

Figs. (4-6): Correlation between serum vitamin D and serum cholesterol, triglyceride and HDL-c respectively in group II. 

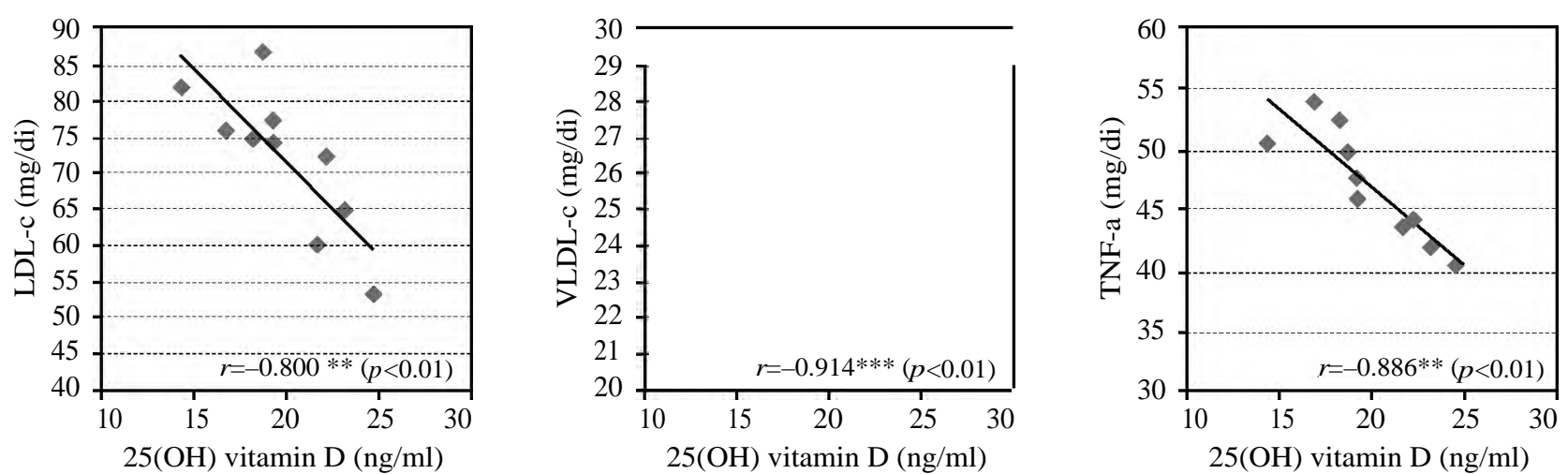

Figs. (7-9): Correlation between serum vitamin D and serum LDL-c, VLDL-c and TNF- $\alpha$ respectively in group II.
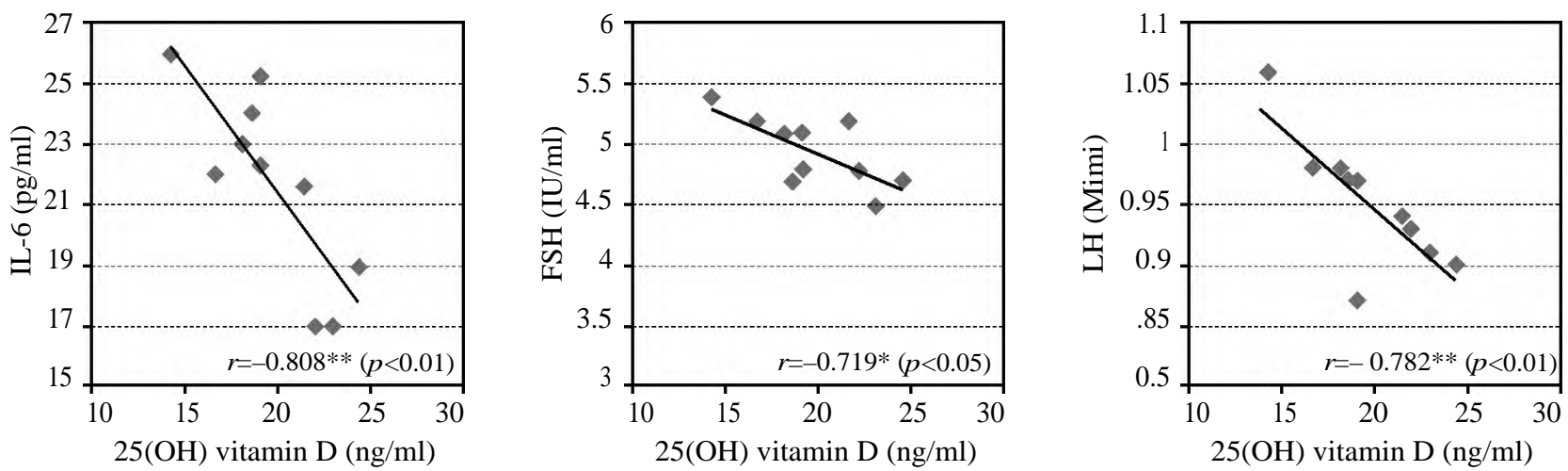

Figs. (10-12): Correlation between serum vitamin D and serum IL-6, FSH and LH respectively in group II.
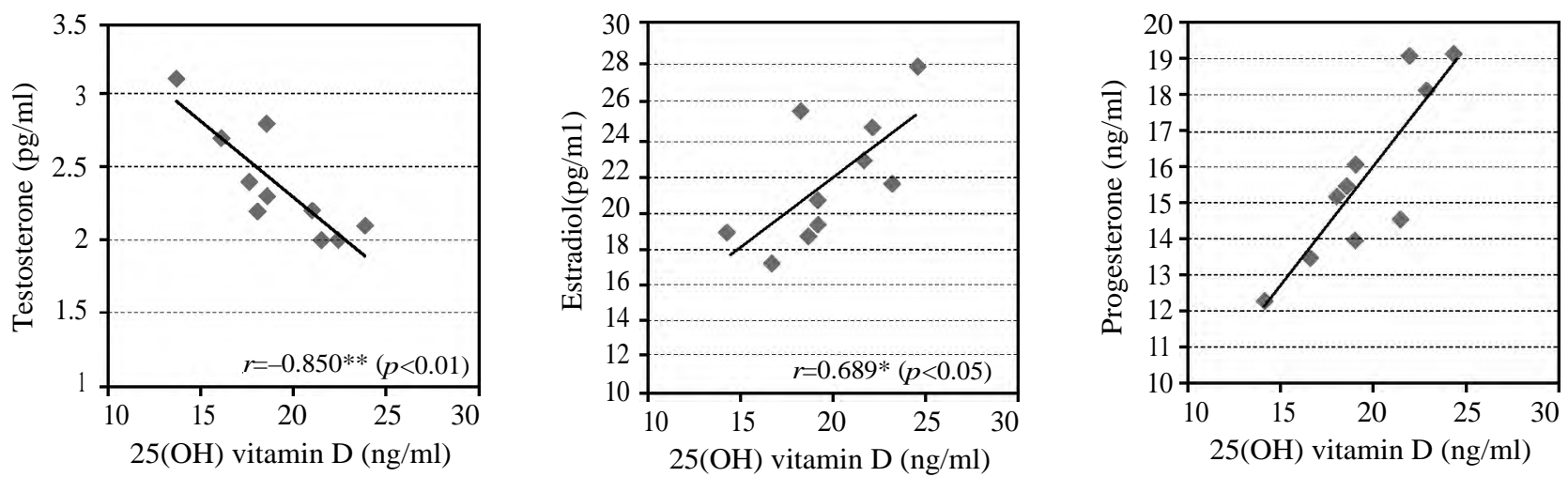

Figs. (13-15): Correlation between serum vitamin D and serum testosterone, estradiol and progesterone respectively in group II.
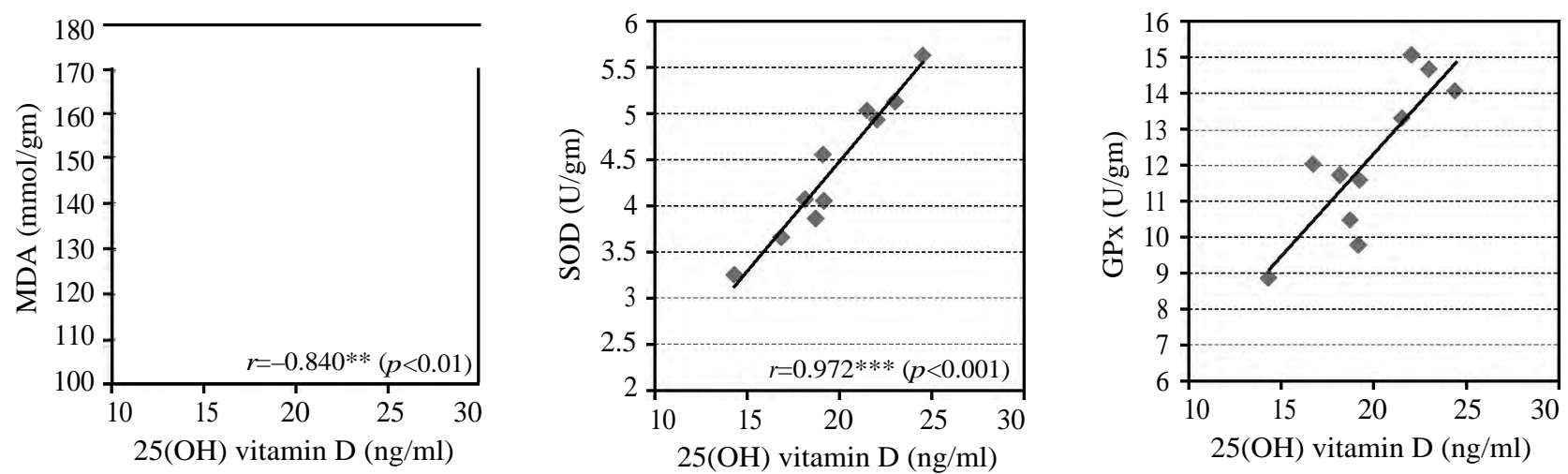

Figs. (16-18): Correlation between serum vitamin D and ovarian MDA, SOD and GPx respectively in group II. 

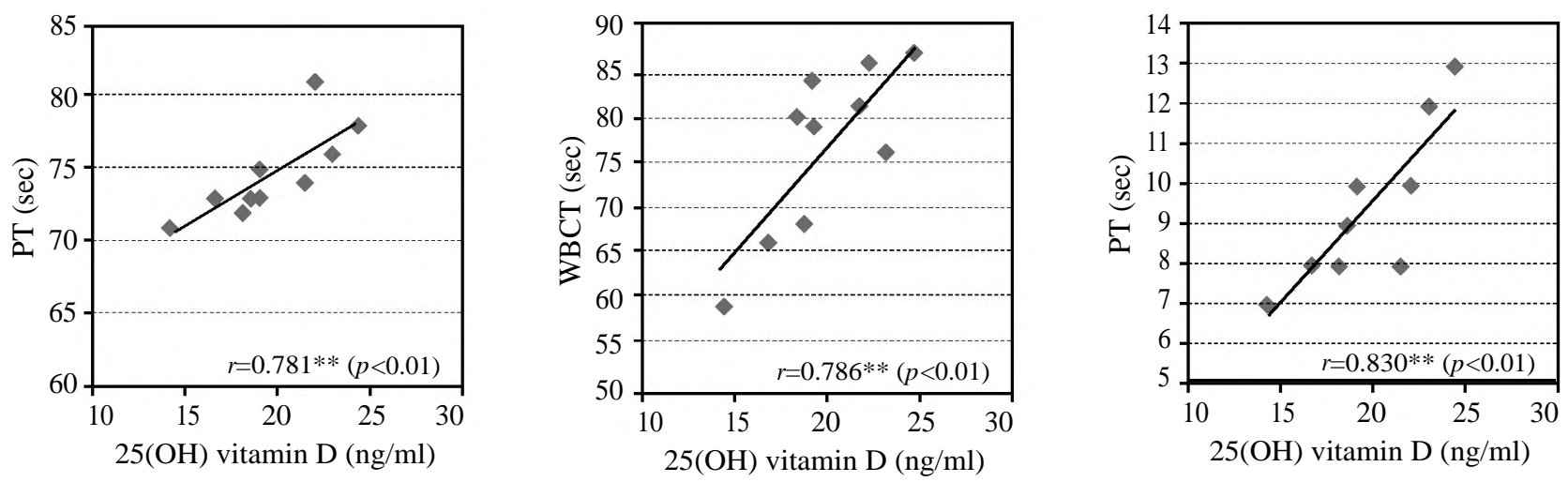

Figs. (19-21): Correlation between serum vitamin D and BT, WBCT and PT respectively in group II.
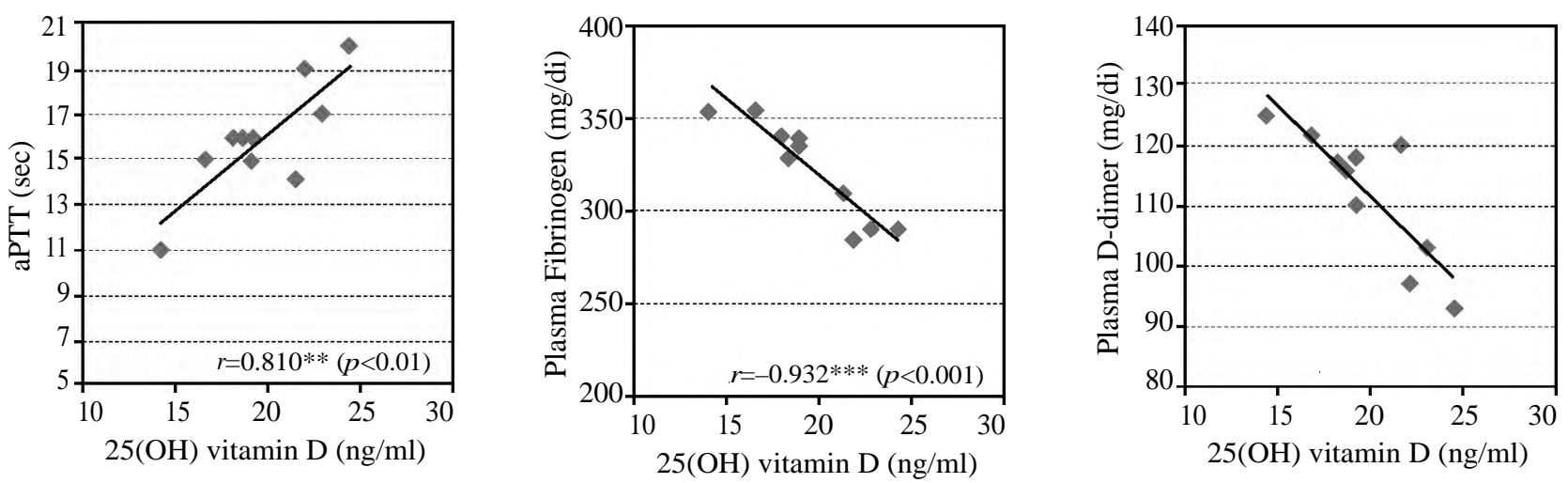

Figs. (22-24): Correlation between serum vitamin D and aPTT, Plasma Fibrinogen and D-dimer respectively in group II.
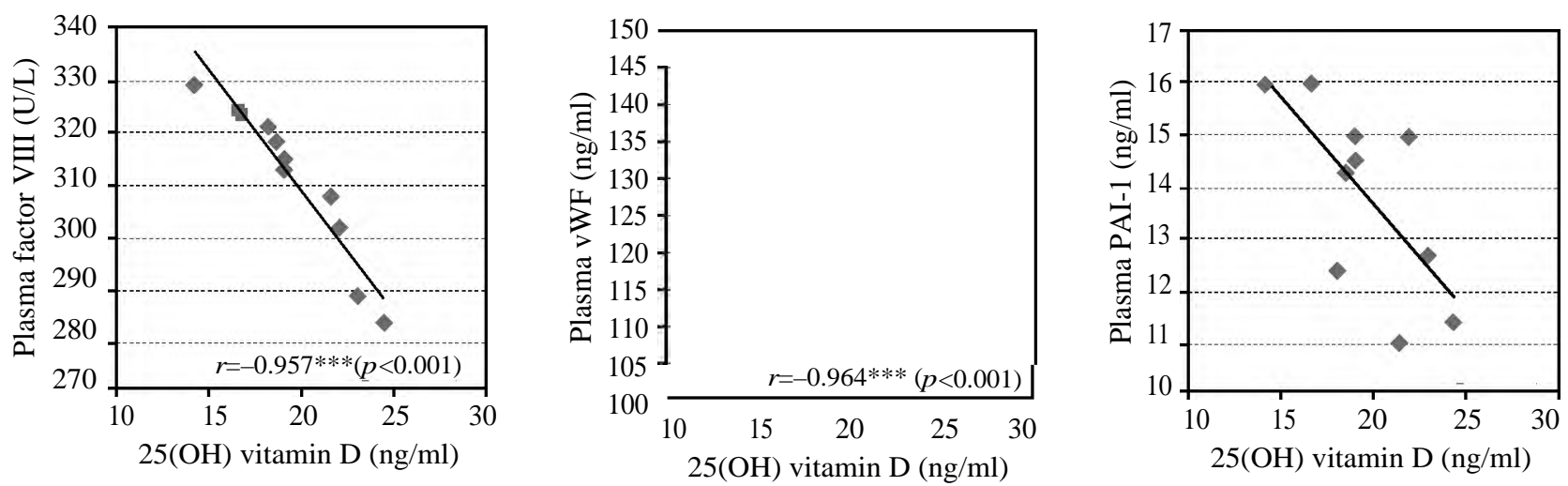

Figs. (25-27): Correlation between serum vitamin D and Plasma factor VIII, vWF and Plasma PAI-1 respectively in group II.

\section{Discussion}

Polycystic ovary syndrome (PCOS) is a common and multifactorial disease associated with both endocrine and metabolic disorder and characterized by hyperandrogenism and ovarian abnormalities, resulting from a disruption in the hypothalamic-pituitary-ovarian axis [42]

Women with PCOS have shown dysregulation of the hemostatic system that may contribute to CV disease (CVD) [43]
The etiology and pathology of PCOS are extremely complicated and management of this disorder remains controversial. Thus, the treatment protocols are applied according to the symptoms of affected women [44]. During recent years, vitamin $\mathrm{D}$ supplementation is also involved in these protocols and differences in the therapeutic efficacy of vitamin D were reported in PCOS patients [45]. The number of studies with regard to effect of vitamin D treatment on ovarian morphology in PCOS is also extremely low [46]. 
Consequently, we examined the therapeutic effects of vitamin D supplementation and the association between its serum level and some biochemical and hemostatic parameters in letrozoleinduced PCOS rat models.

Our results revealed that PCOS rats had lower serum $25(\mathrm{OH})$ vitamin D concentrations, consistent with the findings of previous studies that reported lower serum vitamin D levels in PCOS patients than in non-PCOS subjects [10,47]. However, Ganie et al., [48] did not find such difference in serum $25(\mathrm{OH})$ vitamin D levels. The effect of vitamin D deficiency on metabolic and reproductive dysfunctions in PCOS may be mediated by insulin resistance. Insulin resistance increases hyperandrogenism through insulin increasing ovarian androgen production, and reducing sex hormone-binding globulin (SHBG) production [9] .

In our PCOS model, the serum FSH, LH and testosterone levels were significantly higher in the PCOS group than in the control group with significant negative correlations with vitamin $\mathrm{D}$ serum level. On the other hand, the serum estradiol and progesterone levels were significantly decreased with significant positive correlations with vitamin D level in the PCOS group. Letrozole, a nonsteroidal aromatase inhibitor, reduces conversion of androgens to estrogens in the ovary and results in a condition termed hyperandrogenism with hyperandrogenemia, in which serum estradiol concentration significantly decreases and consequently non-aromatizable androgens such as testosterone increase. Hyperandrogenism as a key regulator in the pathogenesis of a majority of PCOS cases developed cystogenesis by impairing maturation of developing follicles in the ovaries [49]. Moreover, decreased rate of normal ovulations or anovulation and lack of developing CL have been shown to lead to decreased serum progesterone concentrations in the present model, as also seen in PCOS women [50]. Such hormonal disturbance led to constant estrus manifestation in PCO rats [51].

It was also reported that the increase of LH level probably plays an important role in the pathological mechanism of the higher androgen production in the ovaries. It is estimated that the significant increase in LH levels causes an increase in LH/FSH levels, while relative FSH deficiency causes impaired follicle maturation [52].

In this study, we also elucidated the beneficial effects of vitamin D in PCOS treated rats. We found that treatment with vitamin D alleviated the serum gonadotropins, estradiol, progesterone, and testosterone and improved insulin resistance. These findings are in accordance with those of Çelik et al., [46] which showed that vitamin D treatment lowered FSH, LH levels, LH/FSH ratio, and testosterone levels in dehydroepiandrosterone (DHEA) treated rats. The possible mechanism may be the direct stimulatory effect of $1,25(\mathrm{OH}) 2 \mathrm{D} 3$ on the aromatase gene expression in reproductive tissues [53].

Moreover, histological examination of ovaries from the letrozole-induced PCOS rats revealed large cystic follicles filled by granulosa cells and surrounded by dense stroma. However, vitamin D3 supplementation significantly decreased the number of these cystic follicles in the treated PCOS group (letrozole +Vit. D3).

Similar results were reported from other studies that observed an improvement in ovarian morphology after vitamin D treatment [46]. It has been suggested that testosterone stimulates the early stages of follicle growth and vitamin D might inhibit the testosterone-induced early stages of follicular growth [54]. They also reported that the junctional complexes between granulosa cells of the follicles contain high levels of Connexin43 (Cx43) in every stage of follicle development and the expression of $\mathrm{Cx} 43$ was decreased during follicular atresia. In the same study it was reported that high dose testosterone administration downregulates $\mathrm{Cx} 43$ levels and the testosterone-induced downregulation of $\mathrm{Cx} 43$ can be reversed by vitamin D treatment.

VD may play an important role in reproductive functions since Vitamin D receptors (VDRs) have been found in the ovary, endometrium and placenta [55]. Several studies have shown that VD and calcium supplementation may help in ovulation and normalization of menses [56-58]. On the contrary, Ganie et al., [48] observed no relationship to menstrual cyclicity/ovulation. They also found a positive correlation between serum 25OHD and serum total testosterone levels in contrast to the negative correlation reported in our study and in the study of Yildizhan et al., [9]

Moreover, insulin resistance (IR), evidenced by the significantly increased serum glucose and insulin levels in addition to increased HOMA-IR, with significant negative correlations with vitamin D were observed in this study. Insulin excess can cause fulliculogenesis disruption through stimulating androgen production by theca cells and elevating serum-free testosterone levels $[\mathbf{5 9 , 6 0 ]}$. This finding is consistent with previous studies revealing 
a negative association of 25OHD and HOMA-IR in PCOS women [61].

We also elucidated the beneficial effects of vitamin D3 on IR in PCOS treated rats in our study. Vitamin D might directly increase insulin sensitivity via stimulating the expression of insulin receptors in peripheral tissues [62]. Vitamin D receptors are expressed in 2776 genomic positions and modulate the expression of 229 genes in more than 30 different tissues, such as skeleton, brain, breast, pancreas, parathyroid glands, immune cells, cardiomyocytes, and ovaries [63]. Vitamin D may play a role in glucose metabolism by enhancing insulin synthesis and release, and increasing insulin receptor expression or suppression of proinflammatory cytokines that possibly contribute to the development of insulin resistance [63].

More over, in the present study, dyslipidemia manifested by significant increases in total cholesterol, triglyceride, LDL, VLDL (with a significant negative correlation versus serum 25OHD level), and a significant reduction in HDL (with a significant positive correlation versus serum 25OHD level) was observed in PCOS rats. This is probably due to excessive hypersecretion of apolipoprotein $\mathrm{B}$ and very low density lipoprotein (VLDL) from the liver following insulin stimulation, ultimately resulting in hypertriglyceridaemia, low levels of high-density lipoprotein (HDL) and high levels of low-density lipoproteins (LDL) [44] . A previous research has also shown that the 25OHD is inversely correlated with the total cholesterol, triglycerides, body weight, and other metabolic disturbances in PCOS patients suggesting that vitamin D deficiency might be a causal factor in the pathogenesis of PCOS [65]. However, Ganie et al., [48] and Kumar et al., [66] did not demonstrate any relationship between serum 25OHD levels and clinical, metabolic or insulin sensitivity

Vitamin D treatment also significantly improved the dyslipidemia in PCOS treated rats. Von Hurst et al., [61] and Wehr et al., [68] also showed positive effects on insulin sensitivity and IR, lipid profile, menstrual cycle and follicular development with Vitamin D supplementation. In contrast, Jia et al. [45] failed to detect any therapeutic effect of vitamin D3 supplementation in PCOS.

Moreover, the present results revealed a significant increase in serum TNF- $\alpha$ and IL-6 level, with a significant negative correlation versus serum 25OHD level. This is in accordance with results of Rezvanfar et al., [51], who detected higher serum TNF- $\alpha$ concentration in the letrozole-induced
PCOS rats when compared with controls. Vitamin D co-treatment to letrozole-induced PCO rats in this study also significantly prevented the elevation of TNF- $\alpha$ and IL- 6 concentrations and kept it close to that of controls.

Chronic low-grade inflammation has appeared to be a key contributor to the pathogenesis of PCOS. TNF- $\alpha$ and IL- 6 could induce insulin resistance, stimulate the production of androgen and lead to hypothalamic-pituitary-ovarian axis secretion disorder [69]. Emerging data from experimental models and from clinical studies suggest that hyperandrogenism is progenitor of chronic low-grade inflammation that in turn directly stimulates excess ovarian androgen production [70]. It can arrest follicular development via apoptosis in granulosa cells resulting to poor oocyte quality and ultimately progressive follicular atresia through higher serum TNF- $\alpha$ concentrations [71].

Aside from inflammation and hyperglycemia, oxidative stress also contributes to PCOS [72]. In PCOS group in our study, ovarian SOD, and GPX were decreased with significantly higher levels of ovarian MDA. These findings also co-related with the previous researches [18,73]. However, Vitamin D administration had also improved the antioxidant activities and decreased ovarian MDA level. Alqasim et al., [74] also demonstrated the beneficial antioxidant effect of vitamin D in diabetic rats. Vitamin D might impro ve the downregulation of nuclear factor-like 2-kelch-like ECH-associated protein 1 (Nrf2-Keap1) pathway that regulates the expression of antioxidant proteins as well as suppress nuclear factor kappa-light-chain-enhancer of activated B cells (NF- $\kappa \mathrm{B}$ ) and NADPH oxidase activity [75]

Interestingly, our results also showed a prothrombotic state in PCOS group, as reflected by decreased bleeding and clotting times, PT and aPTT together with significant increases in plasma D-dimers, PAI-1 activity and fibrinogen levels. This hypercoagulable state can be explained by insulin resistance, dyslipidemia, inflammatory mediators and oxidative stress that all have been elucidated above in our study.

Elevated levels of fibrinogen, factor VIII, and vWF could lead to hypercoagulability. Fibrinogen is mainly produced by hepatocytes in response to inflammatory cytokines [76]. Fibrinogen levels have also been reported to be elevated in PCOS in other studies [43,77]. However, Kebapcilar et al., [4] reported normal level. 
PAI-1 is the principal inhibitor of fibrinolysis. Increased PAI-1 activity is associated with hypofibrinolysis and may contribute to thrombosis. Consistent with reports of Mannerås-Holm et al., [43], PAI-1 activity was found to be higher in PCOS rats than controls in this study. Low SHBG and high insulin levels were the strongest explanatory factors of high PAI-1 activity in PCOS [78]

Huang et al., [79] also noted a hypercoagulable state with higher FX levels and probable microthrombus formation in the uterine vessels in PCOS women compared with non-PCOS women, which would probably lead to poor microcirculation of endometrium in PCOS women and influence successful embryo implantation as well as subsequent maintenance of pregnancy.

The subclinical inflammation is thought to be an important underlying mechanism leading to coagulation/fibrinolysis abnormalities in PCOS. It was demonstrated that both lean and obese patients with PCOS have increased plasma C-reactive protein levels compared with BMI-matched controls, indicating that the subclinical inflammation seen in PCOS might be related with the presence of the disorder rather than with obesity [80].

It is also well established that insulin resistance/ hyperinsulinemia may alter fibrinolysis by enhancing PAI-1 secretion [81]. Treatment with insulin sensitizers is associated with a reduction in PAI-1 levels that is also paralleled by a decline in circulating androgen levels, suggesting a link between plasma androgens and PAI-1 levels [82].

Notworthy, vitamin D 3 adminstration significantly improved these haemostatic parameters in the treated PCOS group. In line with these findings, Ohsawa et al., [83] found that $1,25(\mathrm{OH}) 2 \mathrm{D}$ exerts anticoagulant effects by upregulating the expression of the anticoagulant glycoprotein, thrombomodulin, and downregulating the expression of a critical coagulation factor, tissue factor, and upregulates thrombomodulin expression in monocytic cells, counteracting the effects of tumor necrosis factor (TNF)-a and oxidized low-densitylipoprotein cholesterol.

Moreover, vitamin D receptor (VDR) knockout mice exhibited an exacerbated multiorgan thrombus formation after lipopolysaccharide injection. These results suggest that the VDR system plays a physiological role in the maintenance of antithrombotic homeostasis [84].
Taking the present findings together, it can be concluded that letrozole-induced PCOS is characterized by a prothrombotic state, as reflected by increased PAI-1 activity, fibrinogen \& D-dimers levels and decreased bleeding, clotting times, PT and aPTT that can be explained by insulin resistance, inflammatory mediators and oxidative stress

Vitamin D might be used as an interesting, economical, and safe therapeutic approach in PCOS patients especially those who had hypovitaminosis D.

Additional studies are required to detect the precise mechanism of PCOS and to investigate the potential therapeutic role of vitamin D in PCOS patients with hypercoagulable state.

\section{Acknowledgment:}

To Prof./Kamal El-Kashish, Pathology Department, Faculty of Medicine, Zagazig University for performing the histological study.

\section{References}

1- ROTTERDAM E.S., ASRM-Sponsored PCOS Consensus Workshop Group: Revised 2003 consensus on diagnostic criteria and long-term health risks related to polycystic ovary syndrome. Fertility and Sterility, 19 (1): 41-47, 2004.

2- MORAN L.J., HUTCHISON S.K., MEYER C., ZOUNGAS S. and TEEDE H.J.: A comprehensive assessment of endothelial function in overweight women with and without polycystic ovary syndrome. Clinical Science, 116 (10): 761-770, 2009.

3- RAJENDRAN S., WILLOUGHBY S.R., CHAN W.P., LIBERTS E.A., HERESZTYN T., SAHA M., MARBER M.S., NORMAN R.J. and HOROWITZ J.D.: Polycystic ovary syndrome is associated with severe platelet and endothelial dysfunction in both obese and lean subjects. Atherosclerosis, 204 (2): 509-514, 2009.

4- KEBAPCILAR L., TANER C.E., KEBAPCILAR A.G. and SARI I.: High mean platelet volume, low-grade systemic coagulation and fibrinolytic activation are associated with androgen and insulin levels in polycystic ovary syndrome. Archives of Gynecology and Obstetrics, 280 (2): 187-193, 2009.

5- LINDHOLM A., BIXO M., ELIASSON M., HUDECOVA M., ARNADOTTIR R., HOLTE J. and POROMAA I.S.: Tissue plasminogen activator and plasminogen activator inhibitor 1 in obese and lean patients with polycystic ovary syndrome. Gynecological Endocrinology, 26 (10): 743-748, 2010.

6- SCHÜRING A.N., SCHULTE N., SONNTAG B. and KIESEL L.: Androgens and insulin-two key players in polycystic ovary syndrome. Gynäkologisch-geburtshilfliche Rundschau, 48 (1): 9-15, 2008.

7- MALKY A.M., ALEANALBALAWI M., YARUB HAFEZ M., HAMAD ALMUTAIRI A., AL-TAISAN S.A., ALI ALGHAMDI A., KHALID ALBRAIK R., ALZAHRANI A.M. and MUHARRAQ Y.J.: The Correlation between 
Vitamin D and Polycystic Ovary Syndrome. Egyptian Journal of Hospital Medicine, 70 (7): 1140-1148, 2018.

8- DIPANSHU S. and CHAKRAVORTY R.: The relationship between vitamin $\mathrm{D}$, insulin resistance and infertility in PCOS women. Gynecol. Obstet. (Sunnyvale), 5 (294): 2161-0932, 2015.

9- YILDIZHAN R., KURDOGLU M., ADALI E., KOLUSARI A., YILDIZHAN B., SAHIN H.G. and KAMACI M.: Serum 25-hydroxyvitamin D concentrations in obese and non-obese women with polycystic ovary syndrome. Archives of gynecology and obstetrics, 280 (4): 559, 2009.

10- LI H.W., BRERETON R.E., ANDERSON R.A., WALLACE A.M. and HO C.K.: Vitamin D deficiency is common and associated with metabolic risk factors in patients with polycystic ovary syndrome. Metabolism, 60 (10): 1475-1481, 2011.

11- ERDÖNMEZ D., HATUN S, ., ÇIZMECIOG LU F.M. and KESER A.: No relationship between vitamin D status and insulin resistance in a group of high school students. Journal of clinical research in pediatric endocrinology, 3 (4): 198-201, 2011.

12- ARDABILI H.R., GARGARI B.P. and FARZADI L.: Vitamin D supplementation has no effect on insulin resistance assessment in women with polycystic ovary syndrome and vitamin D deficiency. Nutrition Research, 32 (3): 195201, 2012.

13- PITTAS A.G., CHUNG M., TRIKALINOS T., MITRI J., BRENDEL M., PATEL K., LICHTENSTEIN A.H., LAU J. and BALK E.M.: Systematic review: Vitamin D and cardiometabolic outcomes. Annals of internal medicine, 152 (5): 307-314, 2010.

14- DEVARAJ S., YUN J.M., DUNCAN-STALEY C.R. and JIALAL I.: Low vitamin D levels correlate with the proinflammatory state in type 1 diabetic subjects with and without microvascular complications. American Journal of Clinical Pathology, 135 (3): 429-433, 2011.

15- TOPALOGLU O., ARSLAN M.S., KARAKOSE M., UCAN B., GINIS Z., CAKIR E., AKKAYMAK ET, SAHIN M., OZBEK M., CAKAL E. and DELIBASI T.: Is there any association between thrombosis and tissue factor pathway inhibitor levels in patients with vitamin D deficiency? Clinical and Applied Thrombosis/Hemostasis, 21 (5): 428-433, 2015.

16- GRUNDMANN M. and VON VERSEN-HaOYNCK F.: Vitamin D-roles in women's reproductive health. Reprod. Biol. Endocrinol., 9: 146, 2011.

17- SEYYED ABOOTORABI M., AYREMLOU P., BEHROOZI-LAK T. and NOURISAEIDLOU S.: The effect of vitamin D supplementation on insulin resistance, visceral fat and adiponectin in vitamin D deficient women with polycystic ovary syndrome: A randomized placebocontrolled trial. Gynecological Endocrinology, 34 (6): 489-494, 2018.

18- REZVANFAR M.A., REZVANFAR M.A., AHMADI A., SAADI H.S., BAEERI M. and ABDOLLAHI M.: Mechanistic links between oxidative/nitrosative stress and tumor necrosis factor alpha in letrozole-induced murine polycystic ovary: Biochemical and pathological evidences for beneficial effect of pioglitazone. Human \& Experimental toxicology, 31 (9): 887-897, 2012.
19- DABAK D.O., KULOGLU T. and OZERCAN M.R.: Effects of vitamin D3 (cholecalciferol) on adriamycin-induced nephrotoxicity. Renal Failure, 31 (5): 400-405, 2009.

20- KAFALI H., IRIADAM M., OZARDAL1 I. and DEMIR N.: Letrozole-induced polycystic ovaries in the rat: A new model for cystic ovarian disease. Archives of medical research, 35 (2): 103-108, 2004.

21- GOLDMAN J.M., MURR A.S. and COOPER R.L.: The rodent estrous cycle: Characterization of vaginal cytology and its utility in toxicological studies. Birth Defects Research Part B: Developmental and Reproductive Toxicology, 80 (2): 84-97, 2007.

22- HOLICK M.F.: Vitamin D status: Measurement, interpretation, and clinical application. Annals of Epidemiology, 19 (2): 73-78, 2009.

23- TIETZ N.: Clinical guide to laboratory tests, 3 rd edition. Lab Anim., 40 (8): 111-119, 1995.

24- TEMPLE R., CLARK P.M. and HALES C.N.: Measurement of insulin secretion in type 2 diabetes: Problems and pitfalls. Diabetic Medicine, 9 (6): 503-512, 1992.

25- MATTHEWS D.R., HOSKER J.P., RUDENSKI A.S., NAYLOR B.A., TREACHER D.F. and TURNER R.C.: Homeostasis model assessment: insulin resistance and $P$ cell function from fasting plasma glucose and insulin concentrations in man. Diabetologia, 28 (7): 412-419, 1985.

26- FRIEDEWALD W.T., LEVY R.I. and FREDRICKSON D.S.: Estimation of the concentration of low-density lipoprotein cholesterol in plasma, without use of the preparative ultracentrifuge. Clinical chemistry, 18 (6): 499-502, 1972.

27- REBAR R.W., MORANDINI I.C., PETZE J.E. and ERICKSON G.F.: Hormonal basis of reproductive defects in athymic mice: Reduced gonadotropins and testosterone in males. Biology of Reproduction, 27 (5): 1267-1276, 1982.

28- FERNANDO B., MARLEY R., HOLT S., ANAND R., HARRY D., SANDERSON P., SMITH R., HAMILTON G. and MOORE K.: N-acetylcysteine prevents development of the hyperdynamic circulation in the portal hypertensive rat. Hepatology, 28 (3): 689-694, 1998.

29- ENGVALL E. and PERLMANN P.: Enzyme-linked immunosorbent assay (ELISA) quantitative assay of immunoglobulin G. Immunochemistry, 8 (9): 871-874, 1971.

30- OHKAWA H., OHISHI N. and YAGI K.: Assay for lipid peroxides in animal tissues by thiobarbituric acid reaction. Analytical Biochemistry, 95 (2): 351-358, 1979.

31- KAKKAR P., DAS B. and VISWANATHAN P.N. (1984): A modified spectrophotometric assay of superoxide dismutase. Indian J. Biochem. Biophys., 21: 130-132, 1979.

32- REDDY K.P., SUBBANI S.M., KHAN P.A. and KUMAR K.B.: Effect of light and benzyl adenine in dark treated growing leaves, changes in the peroxidase activity. Cell Physiol, 24: 987-994, 1995.

33- MARTIN P.: A guide to laboratory animal technology, 2nd ed. Willim Uheine, medical box limited, London. P71, 1981.

34- QUICK A.: Hemorrhage disease and thrombosis. 9 ed. Lea and Febiger, Philadelphia, p. 209, 1966. 
35- ARKIN C.: One stage PT and APTT. Approved Guide line, 16 (3), 1996.

36- ANSELL J.: Impression of prothrombin times monitoring of oral anticoagulants. Am. J. Clin. Path., 98: 237-239, 1992.

37- COOPER J. and DOUGLAS A.: Fibrinogen level as a Predictor of mortality in survivers of myocardial infarction. Fibrinolysis, 5: 105-108, 1991.

38- DECLERCK P., MOMBAERTS P., HOLVOET P., DEMOL M. and COLLEN D.: Fibrinolytic response and fibrin fragment $\mathrm{D}$-dimers in patients with deep venous thrombosis. Thromb. Haemost., 58: 1024-1029, 1987.

39- MANNUCCI P.M., DUGA S. and PEYVANDI F.: Recessively inherited coagulation disorders. Blood, 104: 12431252,2004

40- ITO Y., NOGUCHI K., MORISHIMA Y. and YAMAGUCHI K.: Generation and characterization of tissue-type plasminogen activator transgenic rats. Journal of Thrombosis and Thrombolysis, 45 (1): 77-87, 2017.

41- BARAVALLE C., SALVETTI N.R., MIRA G.A., LORENTE J.A. and ORTEGA H.H.: The role of ACTH in the pathogenesis of polycystic ovarian syndrome in rats: Hormonal profiles and ovarian morphology. Physiological. Research, 56 (1): 67-78, 2007.

42- MANNER D.: Endocrine and metabolic characteristics in polycystic ovary syndrome. Dan. Med. J., 63 (4): 2016.

43- MANNERÅS-HOLM L., LEONHARDT H., KULLBERG J., JENNISCHE E., ODÉN A., HOLM G., HELLSTRÖM M., LÖNN L., OLIVECRONA G., STENER-VICTORIN E. and LÖNN M.: Adipose tissue has aberrant morphology and function in PCOS: Enlarged adipocytes and low serum adiponectin, but not circulating sex steroids, are strongly associated with insulin resistance. The Journal of Clinical Endocrinology \& Metabolism, 96 (2): E304-311, 2011

44- SIRMANS S.M. and PATE K.A.: Epidemiology, diagnosis, and management of polycystic ovary syndrome. Clinical Epidemiology, 6: 1, 2014.

45- JIA X.Z., WANG Y.M., ZHANG N., GUO L.N., ZHEN X.L., LI H and WEI L.: Effect of vitamin D on clinical and biochemical parameters in polycystic ovary syndrome women: A meta-analysis. Journal of Obstetrics and Gynaecology Research, 41 (11): 1791-802, 2015.

46- ÇELIK L.S., KUYUCU Y., YENILMEZ E.D., TULI A., DAGLiOGLU K. and METE U.Ö.: Effects of vitamin D on ovary in DHEA-treated PCOS rat model: A light and electron microscopic study. Ultrastructural. Pathology, 42 (1): 55-64, 2018.

47- GALLEA M., GRANZOTTO M., AZZOLINI S., FAGGIAN D., MOZZANEGA B., VETTOR R. and MIONI R.: Insulin and body weight but not hyperandrogenism seem involved in seasonal serum 25-OH-vitamin D 3 levels in subjects affected by PCOS. Gynecological. Endocrinology, 30 (10): 739-45, 2014.

48- GANIE M.A., MARWAHA R.K., NISAR S., FAROOQI K.J., JAN R.A., WANI S.A., GOJWARI T. and SHAH Z.A.: Impact of hypovitaminosis D on clinical, hormonal and insulin sensitivity parameters in normal body mass index polycystic ovary syndrome women. Journal of Obstetrics and Gynaecology, 36 (4): 508-12, 2016.
49- GOODARZI M.O., DUMESIC D.A., CHAZENBALK G. and AZZIZ R: Polycystic ovary syndrome: Etiology, pathogenesis and diagnosis. Nature Reviews Endocrinology, 7 (4): 219-231, 2011.

50- MEENAKUMARI K.J., AGARWAL S., KRISHNA A and PANDEY L.K.: Effects of metformin treatment on luteal phase progesterone concentration in polycystic ovary syndrome. Brazilian Journal of Medical and Biological Research, 37 (11): 1637-1644, 2004.

51- REZVANFAR M.A., SAEEDI S., MANSOORI P., SAADAT S., GOOSHEH M., SHOJAEI SAADI H.A., BAEERI M. and ABDOLLAHI M.: Dual targeting of TNF- a and free radical toxic stress as a promising strategy to manage experimental polycystic ovary. Pharmaceutical. Biology, 54 (1): 80-90, 2016.

52- TESSARO I., MODINA S.C., FRANCIOSI F., SIVELLI G., TERZAGHI L., LODDE V. and LUCIANO A.M.: Effect of oral administration of low-dose follicle stimulating hormone on hyperandrogenized mice as a model of polycystic ovary syndrome. Journal of ovarian research, 8 (1): 64-77, 2015.

53- KINUTA K., TANAKA H., MORIWAKE T., AYA K., KATO S. and SEINO Y.: Vitamin D is an important factor in estrogen biosynthesis of both female and male gonads. Endocrinology, 141 (4): 1317-24, 2000.

54- LEE C.T., WANG J.Y., CHOU K.Y. and HSU M.I.: 1, 25-Dihydroxyvitamin D 3 increases testosterone-induced 17beta-estradiol secretion and reverses testosteronereduced connexin 43 in rat granulosa cells. Reproductive Biology and Endocrinology, 12 (1): 90-101, 2014.

55- ROSEN C.J., ADAMS J.S., BIKLE D.D., BLACK D.M., DEMAY M.B., MANSON J.E., MURAD M.H. and KOVACS C.S.: The nonskeletal effects of vitamin D: An Endocrine Society scientific statement. Endocrine Reviews, 33 (3): 456-492, 2012.

56- RASHIDI B., HAGHOLLAHI F., SHARIAT M. and ZAYERII F.: The effects of calcium-vitamin D and metformin on polycystic ovary syndrome: A pilot study. Taiwanese Journal of Obstetrics and Gynecology, 48 (2): 142-147, 2009.

57- SELIMOGLU H., DURAN C., KIYICI S., ERSOY C., GUCLU M., OZKAYA G., TUNCEL E., ERTURK E. and IMAMOGLU S.: The effect of vitamin D replacement therapy on insulin resistance and androgen levels in women with polycystic ovary syndrome. Journal of Endocrinological Investigation, 33 (4): 234-238, 2010.

58- FIROUZABADI R., AFLATOONIAN A., MODARRESI S., SEKHAVAT L. and MOHAMMAD TAHERI S.: Therapeutic effects of calcium \& vitamin D supplementation in women with PCOS. Complementary Therapies in Clinical Practice, 18 (2): 85-88, 2012.

59- DUMESIC D.A. and RICHARDS J.S.: Ontogeny of the ovary in polycystic ovary syndrome. Fertility and Sterility, 100 (1): 23-38, 2013.

60- KRISHNAN A. and MUTHUSAMI S.: Hormonal alterations in PCOS and its influence on bone metabolism. Journal of Endocrinology, 232 (2): R99-113, 2017.

61- KOTSA K., YAVROPOULOU M.P., ANASTASIOU O. and YOVOS J.G.: Role of vitamin D treatment in glucose 
metabolism in polycystic ovary syndrome. Fertility and sterility, 92 (3): 1053-1058, 2009.

62- SUNG C.C., LIAO M.T., LU K.C. and WU C.C.: Role of vitamin D in insulin resistance. Bio. Med. Research International, 634195, 2012.

63- RAMAGOPALAN S.V., HEGER A., BERLANGA A.J., MAUGERI N.J., LINCOLN M.R., BURRELL A., HANDUNNETTHI L., HANDEL A.E., DISANTO G., ORTON S.M. and WATSON C.T.: A ChIP-seq defined genomewide map of vitamin D receptor binding: Associations with disease and evolution. Genome Research, 20: 13521360, 2010.

64- TEEGARDEN D. and DONKIN S.S.: Vitamin D: Emerging new roles in insulin sensitivity. Nutrition research reviews, 22 (1): 82-92, 2009.

65- KRUL-POEL Y.H., SNACKEY C., LOUWERS Y., LIPS P., LAMBALK C.B., LAVEN J.S. and SIMSEK S.: The role of vitamin $\mathrm{D}$ in metabolic disturbances in polycystic ovary syndrome: A systematic review. European Journal of Endocrinology, 169 (6): 853-865, 2013.

66- KUMAR A., BARKI S., RAGHAV V., CHATURVEDI A. and KUMAR K.H.: Correlation of vitamin D with metabolic parameters in polycystic ovarian syndrome. Journal of Family Medicine and Primary Care, 6 (1): 115 119, 2017.

67- Von HURST P.R., STONEHOUSE W. and COAD J.: Vitamin D supplementation reduces insulin resistance in South Asian women living in New Zealand who are insulin resistant and vitamin D deficient-a randomised, placebocontrolled trial. British Journal of Nutrition, 103 (4): 549 $555,2010$.

68- WEHR E., PIEBER T.R. and OBERMAYER-PIETSCH B.: Effect of vitamin D3 treatment on glucose metabolism and menstrual frequency in polycystic ovary syndrome women: A pilot study. Journal of Endocrinological. Investigation, 34 (10): 757-63, 2011.

69- LEE K.S., JOO B.S., NA Y.J., YOON M.S., CHOI O.H. and KIM W.W.: Relationships between concentrations of tumor necrosis factor-a and nitric oxide in follicular fluid and oocyte quality. Journal of Assisted Reproduction and Genetics, 17 (4): 222-228, 2000.

70- GONZÁLEZ F.: Inflammation in polycystic ovary syndrome: underpinning of insulin resistance and ovarian dysfunction. Steroids, 77 (4): 300-305, 2012.

71- MURRI M., LUQUE-RAMÍREZ M., INSENSER M., OJEDA-OJEDA M. and ESCOBAR-MORREALE H.F.: Circulating markers of oxidative stress and polycystic ovary syndrome (PCOS): A systematic review and metaanalysis. Human Reproduction Update, 19 (3): 268-288, 2013.

72- YEON LEE J., BAW C.K., GUPTA S., AZIZ N. and AGARWAL A.: Role of oxidative stress in polycystic ovary syndrome. Current Women's Health Reviews, 6 (2): 96-107, 2010.

73- JAHAN S., ABID A., KHALID S., AFSAR T., SHAHEEN G., ALMAJWAL A. and RAZAK S.: Therapeutic potentials of Quercetin in management of polycystic ovarian syndrome using Letrozole induced rat model: A histological and a biochemical study. Journal of Ovarian Research, 11 (1): 26-35, 2018.

74- ALQASIM A.A., NOURELDIN E.E., HAMMADI S.H. and ESHEBA G.E.: Effect of melatonin versus vitamin $\mathrm{D}$ as antioxidant and Hepatoprotective agents in STZinduced diabetic rats. Journal of Diabetes \& Metabolic Disorders, 16 (1): 41-48, 2017.

75- NAKAI K., FUJII H., KONO K., GOTO S., KITAZAWA R., KITAZAWA S., HIRATA M., SHINOHARA M., FUKAGAWA M. and NISHI S.: Vitamin D activates the Nrf2-Keap1 antioxidant pathway and ameliorates nephropathy in diabetic rats. American Journal of Hypertension, 27 (4): 586-95, 2013.

76- MERTENS I. and GAAL L.V.: May; Obesity, haemostasis and the fibrinolytic system. Obesity Reviews, 3 (2): 85 101, 2002.

77- ERDOĞAN M., KARADENIZ M., ALPER G.E., TAMSEL S., ULUER H., CAGLAYAN O., SAYG1L1 F. and Y1LMAZ C.: Thrombin-activatable fibrinolysis inhibitor and cardiovascular risk factors in polycystic ovary syndrome. Experimental and Clinical Endocrinology \& Diabetes, 116 (03): 143-147, 2008.

78- STEGENGA M.E., VAN DER CRABBEN S.N., LEVI M., DE VOS A.F., TANCK M.W., SAUERWEIN H.P. and VAN DER POLL T.: Hyperglycemia stimulates coagulation, whereas hyperinsulinemia impairs fibrinolysis in healthy humans. Diabetes, 55 (6): 1807-1812, 2006.

79- HUANG K., LIAO X., DONG X. and ZHANG H.: Effect of overweight/obesity on IVF-ET outcomes in chinese patients with polycystic ovary syndrome. International Journal of Clinical and Experimental Medicine, 7 (12): 5872-5876, 2014.

80- ESCOBAR-MORREALE H.F., LUQUE-RAMÍREZ M. and GONZÁLEZ F.: Circulating inflammatory markers in polycystic ovary syndrome: A systematic review and metaanalysis. Fertility and Sterility, 95 (3): 1048-1058, 2011.

81- MORANGE P.E. and ALESSI M.C.: Thrombosis in central obesity and metabolic syndrome: Mechanisms and epidemiology. Thrombosis and haemostasis, 110 (04): 669-680, 2013.

82- KEBAPCILAR L., TANER C.E., KEBAPCILAR A.G., ALACACIOGLU A. and SARI I.: Comparison of four different treatment regimens on coagulation parameters, hormonal and metabolic changes in women with polycystic ovary syndrome. Archives of Gynecology and Obstetrics, 281 (1): 35-42, 2010.

83- OHSAWA M., KOYAMA T., YAMAMOTO K., HIROSAWA S., KAMEI S. and KAMIYAMA R.: 1 alpha,25dihydroxyvitamin D (3) and its potent synthetic analogs downregulate tissue factor and upregulate thrombomodulin expression in monocytic cells, counteracting the effects of tumor necrosis factor and oxidized LDL. Circulation, 102 (23): 2867-2872, 2000.

84- AIHARA K.I., AZUMA H., AKAIKE M., IKEDA Y., YAMASHITA M., SUDO T., HAYASHI H., YAMADA Y., ENDOH F., FUJIMURA M. and YOSHIDA T.: Disruption of nuclear vitamin $\mathrm{D}$ receptor gene causes enhanced thrombogenicity in mice. Journal of Biological Chemistry, 279 (34): 35798-35802, 2004. 


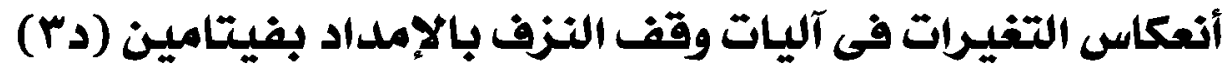

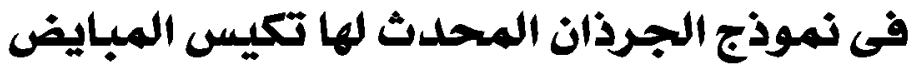 بإستخدام الليتروزول}

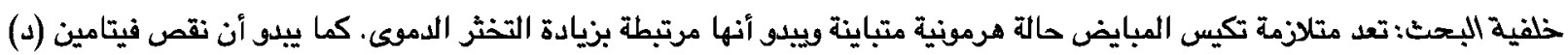

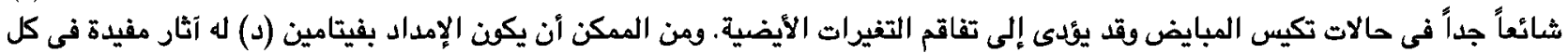

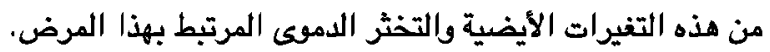

الهدف من البحث: لقد أجريت هذه الدراسة لمعرفة تأثير إعطاء فيتامين (د) على بعض التهائ التغيرات الأيضية ومعاملات الاكسدة والإلتهاب

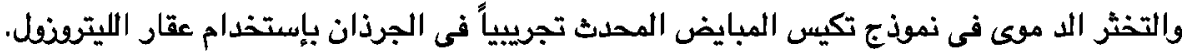

مواد وطرق البحث: أجريت الدراسة على ثلاث مجموعات من إناث الجرذان البيضاء البالغة وتم تقسيمها إلى:

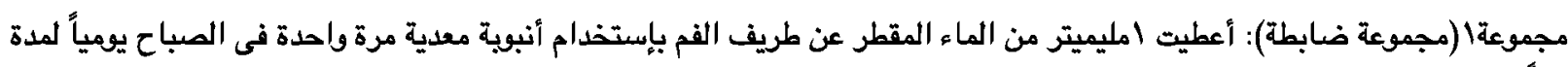
ا Y بوماً.

مجموعة ب:مجموعة مصابة بمرض تكيس المبايض المحدث تجرييياً بواسطة عقار الليترونل بجرعة اميلليجرام/كجم مذاباً فى ماء مقطر

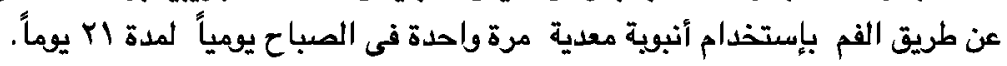

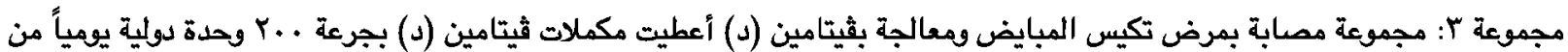

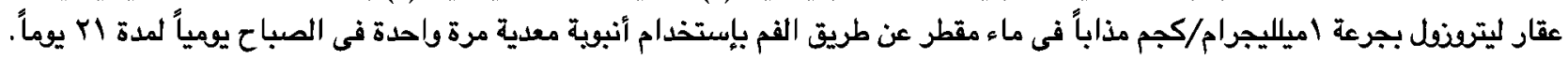

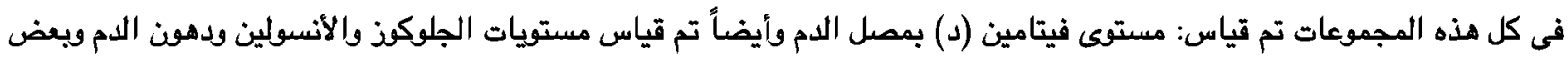

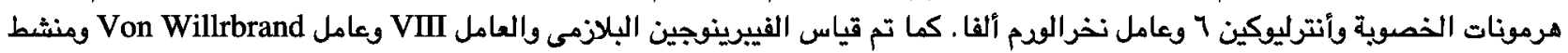

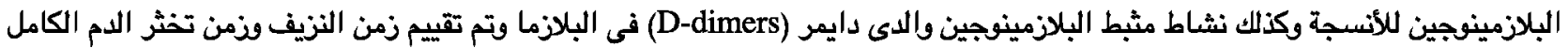

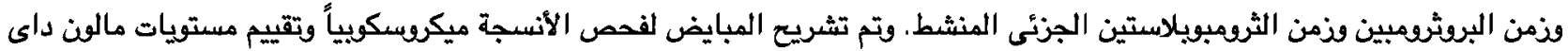

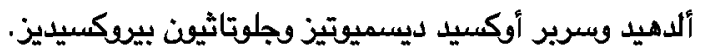

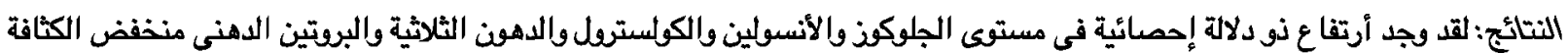

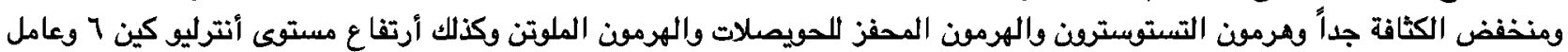

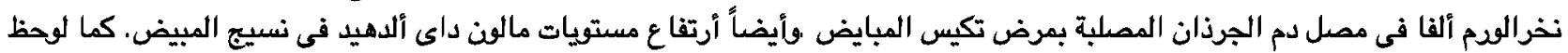

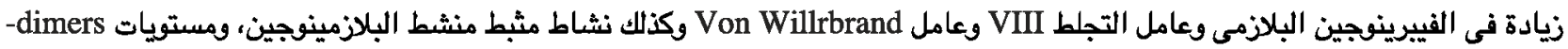

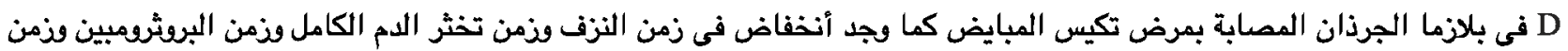

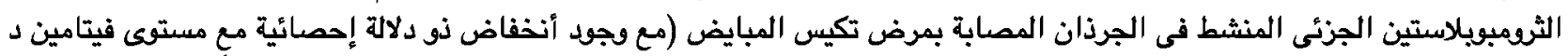

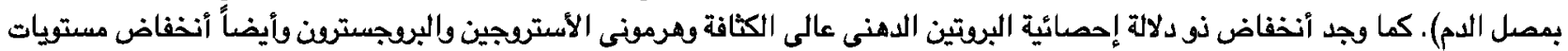

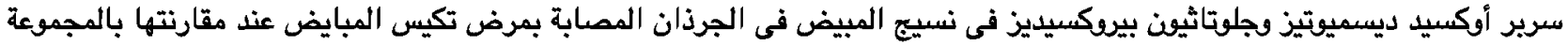

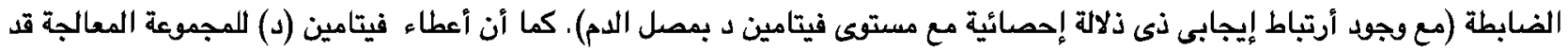

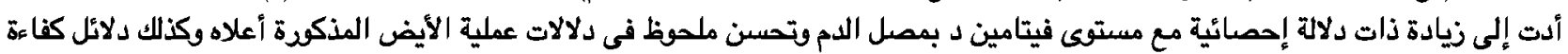
آليات وقف النزف.

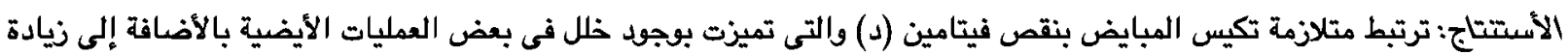

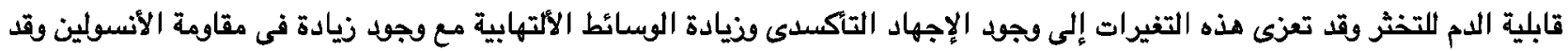

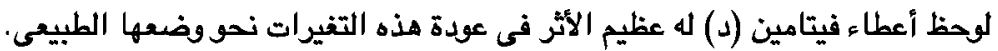

